\title{
Effects of budesonide and probiotics enemas on the colonic mucosa of rats with experimental colitis ${ }^{1}$
}

\author{
Efeito de enemas contendo budesonida e probióticos na mucosa colonica de ratos \\ com colite experimental
}

\author{
Mardem Machado de Souza², José Eduardo de Aguilar-Nascimento ${ }^{3}$, Maria Helena Gomes-da-Silva ${ }^{4}$, Rubens Carlos Junior ${ }^{5}$ \\ 1. Research performed at Department of Surgery, Medical School, Federal University of Mato Grosso (UFMT), Brazil. \\ 2. MD, Assistant Professor, Medical School, Cuiabá University (UNIC). Fellow Master degree, UFMT, Brazil. \\ 3. MD, PhD, Chairman Full Professor, Department of Surgery, Medical School, UFMT, Brazil. \\ 4. MD, PhD, Associate Professor, Nutrition School, UFMT, Brazil. \\ 5. MD, Pathologist, CERMAC, Brazil.
}

\begin{abstract}
Purpose: To investigate the effect of enemas containing probiotics and budesonide on the colonic mucosa in experimental colitis. Methods: Fifty male Wistar rats with experimental colitis induced by $10 \%$ acetic acid enema were randomized to five groups (10 rats each) according to the treatment: group 1 - saline solution, group 2 - budesonide $(0.75 \mathrm{mg} / \mathrm{kg} / \mathrm{day})$, group 3 - probiotics ( $1 \mathrm{mg} /$ day), group 4 - probiotics plus budesonide, and group 5 - control, with not-treated rats. The following variables were studied: body weight, macroscopic and microscopic score of the colonic mucosa, and DNA content of the mucosa. Results: All animals lost weight between the beginning and the end of the experiment $(280 \pm 16 \mathrm{mg}$ versus $249 \pm 21$ $\mathrm{mg}, \mathrm{p}<0.001)$. There was no significant difference among the groups in relation to both the macroscopic and histological score. The budesonide + probiotic group showed higher DNA content than control group $(1.24 \pm 0.15$ versus $0.92 \pm 0.30$ $\mathrm{mg} / 100 \mathrm{mg}$ of tissue, $\mathrm{p}=0.01$ ). Conclusion: Budesonide in addition to probiotics enhance the mucosal trophism in experimental colitis.
\end{abstract}

Key words: Colitis, Ulcerative. Budesonide. Probiotics. Colon. Rats.

\section{RESUMO}

Objetivo: Investigar o efeito da administração retal de probióticos e budesonida na mucosa colônica de ratos com colite experimental. Métodos: Cinquenta ratos Wistar com colite experimental induzida pelo ácido acético à $10 \%$ foram randomizados em 5 grupos (n=10 por grupo) para diferentes tratamentos: grupo 1 - solução fisiológica; grupo 2 - budesonida $(0,75 \mathrm{mg} / \mathrm{kg} /$ dia); grupo 3 - probióticos ( $1 \mathrm{~g} / \mathrm{dia})$; grupo 4 - probióticos associados a budesonida; e finalmente grupo 5 - controle, composto por ratos sem tratamento. As seguintes variáveis foram estudadas: peso corporal, aspecto macroscópico e microscópico da mucosa e conteúdo de DNA da mucosa colônica. Resultados: Todos os animais perderam peso entre o início e o fim do experimento ( $280 \pm 16$ vs $249 \pm 21 \mathrm{~g}$; $\mathrm{p}<0.001)$. Não houve diferença estatística significativa entre os grupos em relação a macroscopia e histologia. O grupo budesonida + probiótico apresentou conteúdo de DNA maior que o grupo controle $(1,24 \pm 0,15$ versus $0,92 \pm 0,30 \mathrm{~g} / 100 \mathrm{~g}$ de tecido; $\mathrm{p}=0,01)$. Conclusão: A associação de budesonida com probióticos acelera o trofismo mucoso na colite experimental.

Descritores: Colite Ulcerativa. Budesonida. Prebióticos. Colon. Ratos.

\section{Introduction}

The medical treatment for ulcerative colitis is limited by its enigmatic ethiopathogeny, incomplete comprehension on both subjacent immunological and inflammatory events and by the lack of a gold standard method to measure the activity of the illness ${ }^{1}$. Thus, the therapeutic intervention is concentrated mainly on the consequences and systemic repercussions of the amplification of the immunological and inflammatory cascades. ${ }^{2}$. The most used drugs used in the treatment of ulcerative colitis are sulfasalazine and its derivatives, corticosteroids, and immunosuppressants. However, the biological treatment with anti-TNF $\alpha$ (infliximab) and other drugs such as transdermic nicotine, heparin, short chain triglycerides, probiotics and antibiotics may benefit the patient ${ }^{3,4}$. Corticosteroids constitute the most effective substances for the treatment of active ulcerative colitis. However, they are not used to maintain remission due to side effects and lack of evidence of its effectiveness for this purpose. The corticosteroids most frequently used in the treatment of ulcerative colitis are hydrocortisone, prednisone, prednisolone and metil-prednisolone. However, these traditional corticosteroids are being gradually substituted by new compounds with less side-effects ${ }^{4}$. A recent metanalysis on the use of budesonide enemas for ulcerative colitis showed similar benefits when compared to conventional glucocorticosteroids ${ }^{5}$. 
Probiotics have been used for various clinical and surgical conditions. There is substantial evidence showing that probiotics are widely beneficial ${ }^{6,7}$. The mechanisms by which probiotic bacteria might exert their beneficial effects and protect against colitis include direct effects on local bacteria and stimulation of protective immune responses. In fact, some clinical and experimental studies have shown that probiotics are beneficial in the treatment of diarrhea and ulcerative colitis. ${ }^{3,8-10}$. The lack of knowledge of the etiology, etiopathogeny and definitive medical treatment of ulcerative colitis encourages experimental studies and thus a number animal model of colitis have been proposed ${ }^{11}$. MacPherson and Pfeiffer ${ }^{12}$ proposed an experimental model of colitis induced by acetic acid in rats. The colon and rectum lesions produced by this method are reproducible in $100 \%$ of the animals and total mucosal recovery occurs 60 days after the induction. Moraes ${ }^{13}$ carried out a similar study and concluded that $10 \%$ acetic acid is useful as an inducing agent of the inflammatory process of the colonic mucosa. There is little information in the literature on the use of probiotics in experimental colitis. Furthermore, the concomitant use of both probiotocs and budesonide in ulcerative colitis has not been investigated. We were not able to found any studies in the literature which examined the combined action of these products in the mucosal recovery in acute colitis. Because of the antiinflamatory action associated with corticoids and the diverse beneficial actions associated with probiotocs ${ }^{14}$, the combined use of these products may benefit the recovery and healing of the colitic mucosal injury. Thus, an experimental study to investigate the use of budesonide and probiotics in experimental colitis could contribute to the discussions on the treatment of colitis. Therefore, the aim of this study was to investigate the effects of retal administration of probiotics and budesonide on the mucosal recovery in experimental acute colitis.

\section{Methods}

Fifty male Wistar rats (250-300g) entered the experiment. The animals were obtained from the Central Animal Laboratory of the Federal University of Mato Grosso. The experiment follows the COBEA (Brazilian Committee on Experimental Animal Care) guidelines. Throughout the whole experiment the animals were kept in appropriate environments inside metabolic cages. They remained for 3 days in the laboratory prior to the experiment for accomodation in 12 hour cycles of light/dark receiving rat chow and water ad libitum. The animals were randomised after induction of colitis into five treatment groups as follows: Group $1(\mathrm{n}=10)$ treated with $1 \mathrm{ml}$ of saline solution (SS 0.9\%); Group 2 ( $\mathrm{n}=10$ ) treated with $1 \mathrm{ml}$ (equivalent to $0.25 \mathrm{mg}$ ) of budesonide (Entcort, Astra Zeneca, Socertalje, Sweden); Group3 $(\mathrm{n}=10)$ treated with $1 \mathrm{~g}$ of probiotics

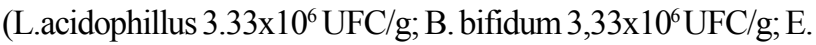
faecium 3.3×10 ${ }^{6}$; Probiotico Vetnil, Vetnil Laboratory, São Paulo); Group $4(\mathrm{n}=10)$ treated with $1 \mathrm{ml}(0.25 \mathrm{mg})$ of budesonide plus 1 $\mathrm{g}$ of the same probiotic as used in the previous group; and Group $5(n=10)$ consisting of rats with colitis and not treated. Blood samples were collect of animals of this group before colitis induction for a normal standard control.

\section{Induction of the colitis}

The method of colitis induction was the same as that used by Mac-Pherson and Pfeiffer ${ }^{12}$ and standardized by Moraes $^{13}$. After fasting for 12 hours the animals underwent mechanical preparation of the colon with enemas containing $20 \mathrm{ml}$ of $0.9 \%$ saline solution in bolus. Polyethylene catheters $6 \mathrm{Fr}$ and $20 \mathrm{~mL}$ syringes were used in the colonic lavage. Thirty minutes after mechanical cleansing each animal was placed in a glass chamber and anaesthetized by inhalation of ethylic ether. Following this, they received an enema containing 0.5 $\mathrm{mL}$ of $10 \%$ acetic acid. Polyethylene catheters $6 \mathrm{Fr}$ similar to those used for the colonic cleansing were used attached to $1 \mathrm{~mL}$ syringes. After the instillation of the acid, the animals were suspended by the tail for 30 seconds. A pilot study with four animals showed that both the cleansing and the colitis induction provided excellent quality of the desired effect. The treatment was started on the first day after colitis induction with the exception of group 5 and was maintained on a daily basis up to the sixth day after the colitis.

\section{Morphology study}

All the animals were killed by inhalation of a lethal dose of ethylic ether. Animals of group 5 were killed the next day after colitis induction and all others on the $7^{\text {th }}$ day after induction. During necropsy, a xifoanal incision was performed and the rectum and colon up to the splenic angle were resected. The specimen was opened longitudinally along the anti-mesentery border for the macroscopic evaluation. The criteria used for the macroscopic evaluation can be seen in Table 1.

TABLE 1 - Criteria for the macroscopic examination of the mucosa of the large intestine

\begin{tabular}{cl}
\hline Score & Morphology \\
\hline 0 & No visible lesion. \\
1 & Regional inflammation, without ulcers. \\
\hline 2 & Linear ulcers without significant inflammation. \\
3 & Linear ulcers with inflammation in one site. \\
4 & $\begin{array}{l}\text { Two or more sites with ulcers and inflammation } \\
\text { of up to } 1 \mathrm{~cm} .\end{array}$ \\
5 & $\begin{array}{l}\text { Two or more sites with ulcers and inflammation } \\
\text { longer than } 1 \mathrm{~cm} .\end{array}$ \\
\hline
\end{tabular}

Biopsies of $1 \mathrm{~cm}$ in length of the rectum containing all layers were collected at the anorectal junction and stored in $10 \%$ formaldehyde vials, and sent for microscopic analysis. Slides stained with haematoxylin and eosin were examined at optical microscopy at 40X, 100X, and 200X magnifications. The microscopic evaluation was carried out by a pathologist unaware of the study design. The criteria ${ }^{15}$ for the microscopic evaluation can be seen in Table 2 . 
TABLE 2 - Microscopic criteria of evaluation

\begin{tabular}{|c|c|c|}
\hline Score & Classification & Description \\
\hline 0 & Normal & $\begin{array}{l}\text { Infiltrated normocellular or } \\
\text { normal hypercellular lamina, } \\
\text { PMNs absent. }\end{array}$ \\
\hline \multirow[t]{3}{*}{1} & Mild & $\begin{array}{l}\text { Diffuse PMNs at the lamina } \\
\text { propria. }\end{array}$ \\
\hline & & $\begin{array}{l}\text { Occasional cryptitis but few } \\
\text { cryptic abscesses. }\end{array}$ \\
\hline & & $\begin{array}{l}\text { Minimal glandular destruction or } \\
\text { ulceration. }\end{array}$ \\
\hline \multirow[t]{3}{*}{2} & Moderate & $\begin{array}{l}\text { Moderate number of PMNs at the } \\
\text { lamina propria. }\end{array}$ \\
\hline & & $\begin{array}{l}\text { Cryptitis and prominent cryptic } \\
\text { abscesses. }\end{array}$ \\
\hline & & Some glandular destruction. \\
\hline \multirow[t]{3}{*}{3} & Serious & $\begin{array}{l}\text { Numerous PMNs with abundant } \\
\text { cryptitis. }\end{array}$ \\
\hline & & Cryptic Abscesses. \\
\hline & & $\begin{array}{l}\text { Extensive cellular destruction. } \\
\text { Prominent ulceration. }\end{array}$ \\
\hline
\end{tabular}

PMN $=$ polimorphonuclear cells

\section{DNA content}

In the rest of the colon all the mucosa was scraped with two glass slides and then weighed, and stored at $20^{\circ} \mathrm{C}$ for DNA quantification using the Giles and Myers technique ${ }^{16}$. The results were expressed in $\mathrm{g} / \mathrm{cm}^{-1}$.

\section{Statistics method}

The comparison of the groups was carried out using either the ANOVA or the Kruskall-Wallis test. Data that need comparisons within group (within-subject analysis) and between group (between-subject analysis) were analyzed by the repeated measures ANOVA. Post-hoc comparisons between groups, when necessary, were carried out using the Tukey test. In the text, the data was presented as mean and standard deviation or mean and variation according to distribution. In graphs data represents the mean and standard error mean (SEM). The statistical significance was set at $5 \%(\mathrm{p}<0.05)$. The tests were carried out using the statistics package SPSS 8.0.

\section{Results}

Four animals of the budesonide group and two animals of each of the other groups of treatment died during the experiment resting 40 animals to complete the study $(p>0.05)$. All the animals that died were necropsied and all presented colonic perforation. During evolution all rats developed diarrhea with blood.

\section{Progress of weight variation}

There was a significant weight loss between the beginning and end of the experiment $(280 \pm 16$ vs $249 \pm 21 \mathrm{~g}$; $\mathrm{p}<0.001$ ) in all the groups. Comparatively the weight loss was greatest in the budesonide group when compared with the group treated with saline solution $(p=0.03)$. The other comparisons were not significant (Table 3 ).

TABLE 3 - Weight evolution (g) among the groups. Data are mean and standard deviation.

\begin{tabular}{lcc}
\hline GROUP & Weight before & Weight after \\
\hline Saline & $287 \pm 11$ & $268 \pm 13^{\dagger}$ \\
\hline Budesonide & $269 \pm 15$ & $241 \pm 6^{\dagger \dagger}$ \\
\hline Probiotic & $287 \pm 16$ & $238 \pm 30^{\dagger}$ \\
\hline Budesonide + Probiotic & $279 \pm 17$ & $247 \pm 15^{\dagger}$ \\
\hline Colitis control* & $276 \pm 16$ & \\
\hline Overall mean & $280 \pm 16$ & $249 \pm 21^{\dagger}$ \\
\hline
\end{tabular}

* Animals killed on the 1 st day of colitis. $\uparrow, p<0.01$ versus Weight Before. $\ddagger, \mathrm{p}=0.03$ versus SS (saline solution) ANOVA with repeated measures.

\section{Morphology study of the mucosa}

Macroscopic evaluation of the mucosa showed ulcers in all the groups (Figure 1). In all the groups the average score was 5 varying from 3 to 5 or 4 to 5 depending on the group $(\mathrm{p}=0.47)$. The findings at microscopy were consistent with macroscopy showing intense inflammatory neutrophilic infiltration with presence of cryptitis and cryptic abscesses (Figure 2). There was no significant difference between the groups $(p=0.65)$. The average score in all of them was 3 with the variation always from 2 to 3 .

\section{DNA Content}

The findings of the DNA content of the mucosa can be seen in Figure 3. The budesonide+probiotic showed greater DNA content than the control group (group 5) $(1,24 \pm 0,15$ versus $0,92 \pm 0,30 \mathrm{~g} / 100 \mathrm{~g}$ of tissue; $\mathrm{p}=0,04)$. The comparisons between the control group and the other groups (saline: $1,17 \pm 0,27 \mathrm{~g} / 100 \mathrm{~g}$ of tissue, $\mathrm{p}=0,32$; probiotic: $1,19 \pm 0,31 \mathrm{~g} /$ $100 \mathrm{~g}$ of tissue, $\mathrm{p}=0,38$; budesonide: $1,21 \pm 0,42 \mathrm{~g} / 100 \mathrm{~g}$ of tissue; $p=0,12$ ) did not show any significant difference. There was no difference in the comparison between the four treatment groups $(\mathrm{p}=0,87)$.

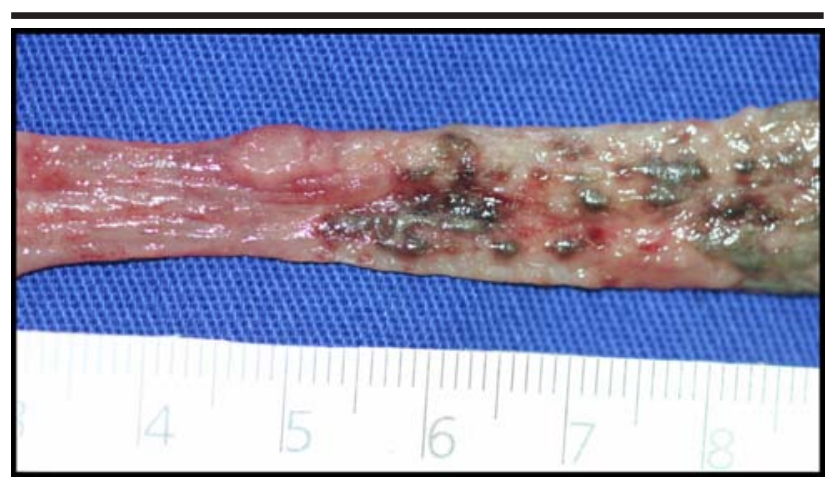

FIGURE 1 - Macroscopic examination showing colonic mucosa with ulceration. 


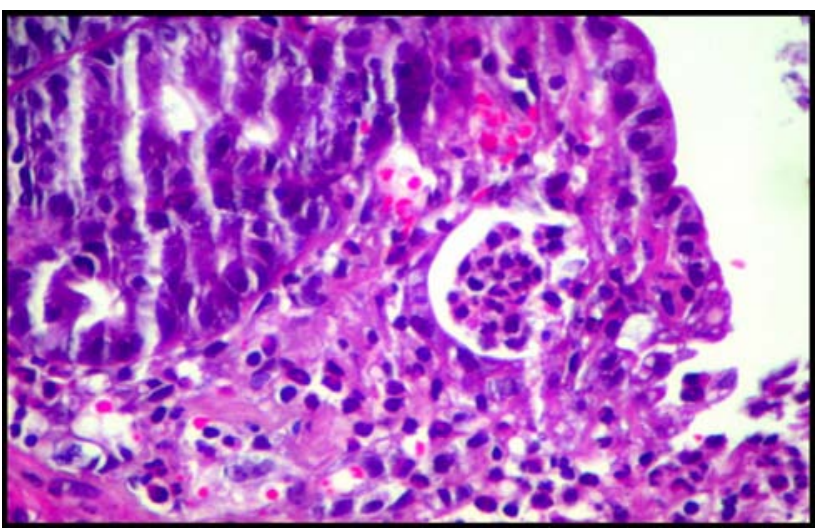

FIGURE 2 - Histological study on colon mucosa showing accentuated inflammatory neutrophilic infiltration, cryptitis, and cryptic abscesses. $H \& E 200 x$

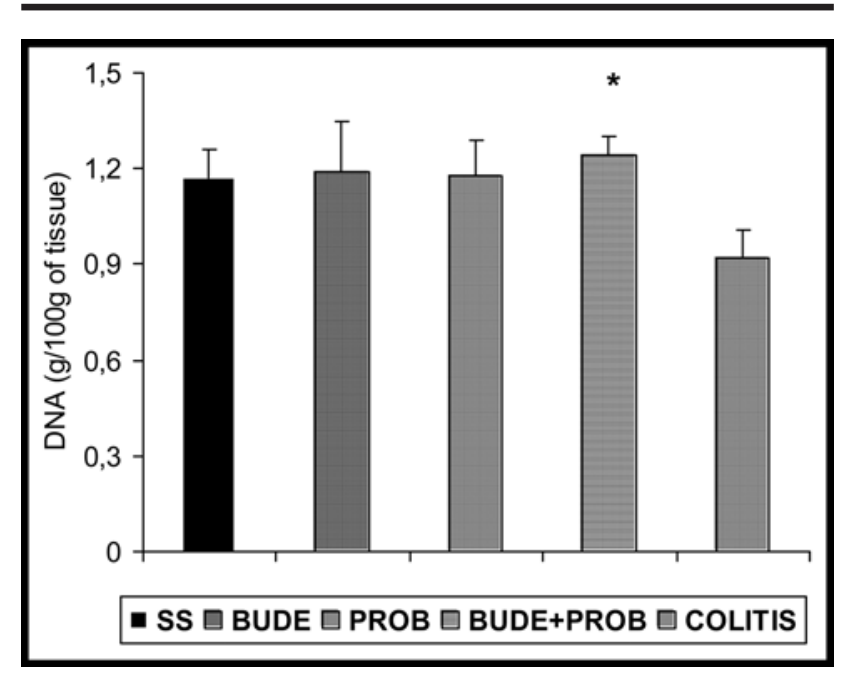

FIGURE 3 - DNA content in the different groups. *, $\mathrm{p}=0.01$ vs. Colitis. Data represents the mean and SEM. $\mathrm{SS}=$ saline solution, group $1 ; \mathrm{BUDE}=$ budesonide, group 2; PROB = probiotic, group 3; $\mathrm{BUDE}+\mathrm{PROB}=$ Budesonide + probiotic, group 4; COLITIS $=$ control group.

\section{Discussion}

Our study confirmed that this animal model of colitis induced by $10 \%$ acetic acid is an excellent method of acute colitis.. Both the macroscopic and microscopic findings showed that the $10 \%$ acetic acid enemas cause a diffuse, acute and necrotizing inflammatory process. Other authors have reported the effectiveness of acetic acid as an inducer of experimental colitis as well as having a tendency for spontaneous cure ${ }^{12,13}$. Ulcerations along the colonic mucosa was seen in all groups without any significant difference. MacPherson and Pfeiffer ${ }^{12}$ and also Moraes $^{12,17}$, in their studies, carried out histological evaluations for the phase of induction and repair since they studied the animals for up to sixty days post-colitis induction. In this study we opted to perform the morphological evaluations of the specimens in a short term $^{15}$. It was found that the acetic acid promoted colitis in all the groups causing edema, hemorrhaging, ulcers, abscesses and extensive cell destruction. This result suggested that a week was too short a time for the morphological study aiming to compare the reepithelialization of the mucosa after the acid damage. However, as we had found morphological differences in a previous study following the same model ${ }^{18}$ and then, we opted for the same time point of observation aiming to evaluate the therapeutic effects of the different treatments on the mucosa. The DNA content in the probiotic-budesonide group was greater when compared to the control group with colitis. No other treatment reaches the significance level when compared to controls. As DNA is a marker of cell mass, this finding suggests that there was a gain in cellularity of the intestinal mucosa with the association of probiotics and corticoids. This result implies that the association of a powerful steroidal anti-inflammatory agent wtih probiotic bacteria may be beneficial. The probiotics produced short chain fatty acids which are powerful trophic agents of the mucosal epithelium ${ }^{18}$. Other mechanisms by which probiotic bacteria might improve colitis include direct effects on local bacteria and stimulation of protective immune responses. However, based on this present data it can be seen that on their own the probiotics do not promote the desired trophic effect. On the other hand, in association with anti-inflammatory action the effect was more significant. This result is very significant and infers that this association may improve trophism and repair of the mucosa in colitis. With more than 400 microorganism species residing in the human gastrointestinal tract, their overall balance can profoundly influence gut ecology and health. Intestinal bacteria produce toxins and antitoxins, alter chemical composition of foods and drugs, produce and degrade vitamins, degrade dietary toxins and inhibit the growth of certain pathogens. Gut-derived products may also play a role in increasing the systemic immune inflammatory response. Several observations, both on humans and animal models, emphasized the importance of bacterial flora in inflammatory bowel disease pathogenesis, justifying the current interest towards emerging antibiotic and probiotic therapies aimed at the manipulation of enteral flora ${ }^{20}$ Human studies suggest beneficial bacteria have a positive effect in colitic patients. Probiotics may promote a positive immune response and concluded it may have the potential to promote and fortify the gut immunological barrier ${ }^{21}$. Two recent studies showed that probiotics maintain patients with inflammatory bowel disease in remission ${ }^{22,23}$. In conclusion, the overall results suggest that the association of probiotics and budesonide in enemas is effective to increase cellularity in experimental acute colitis. Although the effect is modest at macro and microscopic examinations, histochemically there is greater cell mass in the colonic mucosa shown by the increased mucosal DNA content. 


\section{References}

1. Abreu MT. The pathogenesis of inflammatory bowel disease: translational implications for clinicians. Curr Gastroenterol Rep. 2002; 4: 481-9.

2. Amaral R, Pizzol JR AD, Portinho CP, Braga P,Moreira LF, Gus P. Enemas de ciclosporina (cya) no tratamento de colite ulcerativa induzida, em ratos, por ácido acético. Rev Bras Coloproctol. 2001; 21: 219-27.

3. Shanahan F. Probiotics in inflammatory bowel diseasetherapeutic rationale and role. Adv Drug Deliv Rev. 2004; 56: 809-18.

4. Bickston SJ, Comerford LW, Cominelli F. Future therapies for inflammatory bowel disease. Curr Gastroenterol Rep. 2003; 5: 518-23.

5. Nos P, Hinojosa J, Gomollon F, Ponce J. Metaanálisis sobre la efectividad de la budesonida en la enfermedad inflamatória intestinal. Med Clin. 2001; 116: 47-53.

6. Van Niel CW, Feudtner C, Garrison MM, Christakis DA. Lactobacillus therapy for acute infectious diarrhea in children: a meta-analysis. Pediatrics. 2002; 109: 678-84.

7. Huang JS, Bousvaros A, Lee JW, Dias A, Davidson EJ. Efficacy of probiotic use in acute diarrhea in children. a meta-analysis. Dig Dis Sci. 2002; 47: 2625-34.

8. Fedorak RN, Madsen KL. Probiotics and the management of inflammatory bowel disease. Inflamm Bowel Dis. 2004; 10:286-99.

9. Herias MV, Koninkx JF, Vos JG, Huis Veld JH, Van DJE. Probiotic effects of Lactobacillus casei on DDS-induced ulcerative colitis in mice. Int J Food Microbiol. 2005; 103:143-5.

10. Campieri M, Gionchetti P. Probiotics in inflammatory bowel disease: new insight to patogesis or a possible therapeutic alternative? Gastroenterology. 1999; 116: 1246-49.

11. Rodrigues LV. Aspectos morfológicos e morfométricos do processo inflamatório na colite difusa induzida por ácido acético a $10 \%$, em ratos e tratada com ácido 5amino-2-hidroxibenzóico (5-ASA) ou com extrato aquoso de Myracroduon urundeuva Fr. All, (Aroeira-do-sertäo) [Tese-Doutorado]. Universidade Federal de São Paulo Escola Paulista de Medicina; 1999.

12. Mac Pherson BR, Pfeiffer CJ. Experimental production of diffuse colitis in rats. Digestion. 1978; 17: 135-50.
13. Moraes RS. Inducão da colite difusa pela instilacão de ácido acético: estudo experimental em ratos [Dissertacão - Mestrado]. Universidade Federal do Paraná; 1987.

14. Dock DB, Latorraca MQ, Aguilar-Nascimento JE, Gomes $\mathrm{MH}$. Probiotics enhance recovery from malnutrition and lessen colonic mucosal atrophy after short-term fasting in rats. Nutrition. 2004; 20: 473-6.

15. Sandborn WJ, Tremaine WJ, Schroeder KW, Steiner BL, Batts KP, Lawson GM. Cyclosporine enemas for treatment-resistant, mildly to moderately active, leftsided ulcerative colitis. Am J Gastroenterol. 1993; 88: 640-5.

16. Giles KW, Myers A. An improved diphenylamine method for the estimation of deoxyribonucleic acid. Nature. 1965; 206: 93-6.

17. Moraes RS. Aspectos morfológicos da colite difusa induzida pelo acido acético à $10 \%$ e tratada com enemas de acido 5-amino-2-hidroxibenzóico. Estudo experimental em ratos Sprague-Dawley [Tese-Doutorado]. Universidade Federal de São Paulo - Escola Paulista de Medicina; 1989.

18. Aguilar-Nascimento JE, França-da-Silva LR, de-Oliveira AF, Gomes-da-Silva MH. Enhanced mucosal reepithelialization induced by short-chain fatty acids in experimental colitis. Braz J Med Biol Res.1999; 32: 961-6.

19. Roediger WE, Millard S. Colonocyte metabolism. Gut. 1996; 38: 792-3.

20. Cui HH, Chen CL, Wang JD. Effects of probiotic on intestinal mucosa of patients with ulcerative colitis. World J Gastroenterol. 2004; 10: 1521-5.

21. Malin M, Suomalainen H, Saxelin M, Isolauri E. Promotion of $\operatorname{IgA}$ immune response in patients with Crohn's disease by oral bacteriotherapy with Lactobacillus GG. Ann Nutr Metabol. 1996; 40:137-45.

22. Zocco MA, dal Verme LZ, Cremonini F, Piscaglia AC, Nista EC, Candelli M, Novi M, Rigante D, Cazzato IA, Ojetti V, Armuzzi A, Gasbarrini G, Gasbarrini A. Efficacy of Lactobacillus GG in maintaining remission of ulcerative colitis. Aliment Pharmacol Ther 2006; 23:1567-74.

23. Gibson G, Roberfroid M. Dietary modulation of the human colonic microbiota: introducing the concept of probiotics. J Nutr. 1995; 125:1401-12.

\section{Correspondence:}

Mardem M. de Souza

R. Dom Antonio Malan, 631/201

78015-600 - Cuiabá - MT - Brazil
Conflict of interest: none Financial source: none

Received: August 11, 2006 Review: September 19, 2006 Accepted: October 23, 2006

\section{How to cite this article:}

Souza MM, Aguilar-Nascimento JE, Gomes-da-Silva MH, Carlos JR R. Effects of budesonide and probiotics enemas on the colonic mucosa of rats with experimental colitis. Acta Cir Bras. [serial on the Internet] 2007 Jan-Feb;22(1). Available from URL: http://www.scielo.br/acb. 